\title{
Criminological Characteristic of Corruption Crimes in Russia
}

\author{
Polishchuk Nikolaj Ivanovich \\ Department of the theory of the state and right, international \\ and European law Address: the Academy of the Federal \\ Penal Service of Russia \\ Ryazan, Russia \\ nik-polishchuk@yandex.ru
}

\author{
Vassenkov Maxim Vladimirovich \\ Pskov State University \\ Pskov, Russia \\ kafoppd@ rambler.ru
}

\author{
Fedotova Evgenia Nikolaevna \\ Department of criminology and organizations of prevention \\ of crimes Address: the Academy of the Federal Penal \\ Service of Russia \\ Ryazan, Russia \\ evgenija_kaz@mail.ru
}

\author{
Menshikov Alexander Andreevich \\ Pskov State University \\ Pskov, Russia \\ amen_koff@mail.ru
}

\author{
Smirnova Irina Nikolaevna \\ Department of Law Enforcement, Criminal Law and Procedure \\ Pskov State University \\ Pskov, Russia \\ kafoppd@rambler.ru
}

\begin{abstract}
In article questions of anti-corruption policy of law of the Russian Federation are investigated, the reasons and conditions the generating corruption crimes are opened, the criminological portrait of the person making this socially dangerous act is proved.
\end{abstract}

Keywords: corruption, anti-corruption policy, corruption crimes, identity of the criminal, official position, bribery, anticorruption movement

\section{INTRODUCTION}

The international anti-corruption movement Transparency International published the Corruption Perception Index (CPI) for 2018, according to which Russia took 138th place out of 180 countries. Over the past three years, the Russian Federation scored 29 points, and this year it lost one point and fell to three positions. Papua New Guinea, Lebanon, Iran, Guinea and Mexico scored the same points.

Corruption Perception Index (hereinafter - CPI) is a composite index by which the level of corruption in the public sector of various countries is measured. It is compiled on the basis of annual surveys of experts and entrepreneurs conducted by independent organizations around the world since 1995 . The countries of the world are ranked on a scale from 0 to 100 , where zero indicates the highest level of perception of corruption, and one hundred the lowest.

It should be noted that the group of leaders underwent insignificant changes: Denmark took the first place (88 points), New Zealand (87 points) second, and Finland, Sweden, Switzerland, and Singapore ( 85 points each) came in third. At the end of the list are Somalia (10 points), Syria and South Sudan (13 points). The United States received 71 points (4 points less than last year) and for the first time in a long time could not get into the top twenty. Brazil also lost two points, earning the lowest CPI in seven years - now it has 35 points.

In the group of CIS countries and Russia's geographical neighbors, Tajikistan made the biggest breakthrough - from 21 to 25 points. Ukraine (from 30 to 32 points) and Moldova (from 31 to 33 points) improved their position by two points. Some countries remained with the same results (Kazakhstan 31 points, Armenia 35 points, Kyrgyzstan 29 points). Azerbaijan lost as much as 6 points: in the CPI -2018 , the country received 25 points against 31 in 2017 [6].

Note that in 2010 Russia took the 154th place in the presented rating. However, despite the positive dynamics, the scale of corruption in our country is critical. Thus, the Russian News Agency published data on the damage caused to the 
national economy by corruption crimes, which in 2018 amounted to 65.7 billion rubles [8]. Note that in some studies, the damage from corruption-related crimes in 2017 was estimated at 39.6 billion rubles. The average size of a bribe for crimes identified by law enforcement agencies, excluding petty bribery, amounted to 2.1 million rubles. The number of persons who committed corruption-related crimes as part of an organized group or criminal community (criminal organization) increased by $0.4 \%$; the proportion of corrupt officials in the judiciary increased by $33.3 \%$, and by $10.3 \%$ in the system of the Ministry of Defense [3, p. 42].

\section{METHODS}

Federal Law of December 25, 2008 No. 273-FZ On Combating Corruption defines it as abuse of official position, giving a bribe, receiving a bribe, abuse of authority, commercial bribery or other illegal use by an individual of his official position contrary to the legitimate interests of society and the state for obtaining benefits in the form of money, valuables, other property or property-related services, other property rights for oneself or for third parties, or the illegal provision of such benefits s specified person other individuals, as well as the commission of these acts on behalf of or for the benefit of a legal person [5].

Decree of the Prosecutor General's Office of Russia No. 853/11, Ministry of Internal Affairs of Russia No. 5 dated December 25, 2018 «On the Enactment of the Lists of Articles of the Criminal Code of the Russian Federation Used in the Formation of Statistical Reporting» establishes a rather extensive list of crimes related to corruption, some of which are recognized as such, in the presence of a certain sign.

\section{RESULTS}

According to the All-Russian Research Institute of the Ministry of Internal Affairs of Russia, bribery is the main share in the structure of corruption crime - 60.6\%; fraud committed with the use of official position - $25.5 \%$; appropriation or embezzlement using official position $-13.1 \%$, official forgery $-7.7 \%$, etc. [3, p. 41]. This is also confirmed by the data of the Judicial Department under the Supreme Court of the Russian Federation. Therefore, it can be stated that annually the most common corruption crimes are acts provided for in Art. 290, 291, 291.1, 291.2 of the Criminal Code, which account for the vast majority of crimes included in the study group [9].

The proportion of bribery in the total number of crimes over the past ten years is approximately $0.7 \%$. This indicator is not stable, since in 2009 it was $0.6 \%$, in $2015-0.9 \%$, in $2018-0.8 \%$ [9]. And although the share of corruption crimes in the total number of committed criminal acts in Russia is not large, its traditionally high level of latency should be taken into account. According to individual authors, actual corruption crime is several times higher than detected. The criminologists studying this problem estimate the latency of bribery at the level of 90-98\% [2, p. 111-120]. Obviously, latency entails impunity, which in turn leads to new, more dangerous corruption crimes.
In detailing the criminological characteristics of bribery, it should be noted that prior to the introduction in 2016 of the Criminal Code of the Russian Federation, Art. 291.2. (petty bribery) the ratio between giving and receiving a bribe was distributed as follows: $65 \%$ for giving, $35 \%$ for receiving. With the introduction of the above article, the following indicators have been established: $21 \%$ fall on bribes, $25 \%$ fall on the country house, $54 \%$ fall on mediation in bribery and petty bribery [10]. In $85 \%$ of cases, taking a bribe is carried out under aggravating circumstances (parts 3-6 of Art. 290 of the Criminal Code of the Russian Federation), while on average over the past 5 years in $65 \%$ of cases, guilty persons are punished and measures not related to deprivation of liberty. In 2012, 2013, the similar indicator amounted to more than $84 \%$, which of course did not correspond to the nature and degree of social danger of the crime.

\section{DISCUSSION}

Currently, judicial practice in the studied area has been adjusted: in 2018, 53.6\% of those guilty were convicted of taking bribes under aggravating circumstances (parts 3-6 of Article 290 of the Criminal Code of the Russian Federation); About $15 \%$ of persons are condemned for giving a bribe to imprisonment, respectively, to penalties and measures not related to imprisonment $-85 \%$.

The identity of the offender convicted of receiving a bribe can be represented as follows: this is a man (83\%), aged 3049 years $(64 \%)$, with higher education $(86 \%)$, a state or municipal employee (35\%), or law enforcement officer bodies or prosecutors $(40 \%)$.

It is interesting to note that over 5 years the identity of the offender - the recipient of a bribe has changed. As of 2014, the portrait of this category of people looked as follows - this is a man (77\%), aged 30-49 years (54\%), having higher education $(85 \%)$, who is a state or municipal employee $(43 \%)$, or law enforcement or prosecutor (34\%).

From the data presented, it can be concluded that over the past 5 years, the number of women who committed a crime under Art. 290 of the Criminal Code of the Russian Federation, and the number of law enforcement officers and prosecutors responsible for its commission has increased. An increase in the latter indicator may be associated with an increase in the detection and registration of such crimes. Despite this identified trend, it should be assessed as very dangerous. Corruption in law enforcement is the main reason hindering the implementation of the national anti-corruption program. The above is a factor that destabilizes their activities, determines the growth of crime, and thus poses a threat to the security of the state as a whole. In this regard, one of the main directions of the state's anti-corruption policy should be the improvement of ways to combat corruption in law enforcement by developing a set of measures that can neutralize the diversity of determinants.

Considering the identity of the offender who committed the bribe, it should be noted that according to judicial statistics, the majority of people convicted of this crime are men $(84 \%)$ aged $30-49(54 \%)$ with higher or secondary special education $(53 \%)$, workers or persons engaged in 
entrepreneurial activity (34\%). It is necessary to pay attention to the fact that over the past 5 years, the portrait of the analyzed category of criminals has not changed significantly.

Characterizing the identity of the criminal bribe taker, we single out the moral and psychological features characteristic of this category of persons. Persons convicted of receiving a bribe have hyperbolized material needs, reluctance to adhere to generally recognized moral and normatively-fixed rules of behavior, an acute need to live beyond income. Convicted for giving a bribe is characterized by the commission of the studied crimes under the pressure of life circumstances, which, in their opinion, cannot be solved in law-abiding ways. However, the objective motive for such behavior is the desire to quickly enrich the bribe taker and quickly solve the existing problem for the bribe giver [1, p. 103-110].

The mechanism of corruption crimes consists of three stages: initial, main and final. Let us analyze them using the example of taking a bribe. At the first stage, the subject of the crime informs other persons of their readiness to take action in favor of the person concerned. In turn, the actions of the victim can be characterized as purposefulness (provocation) and meaninglessness. At the main stage, the criminal intent is realized, by means of the subject using his official position. The methods of committing corruption crimes are infinitely diverse, they are improved from year to year, evolve along with anti-corruption legislation. Corruptionists, as a rule, themselves choose the place, time and method of fulfilling their intentions, while simultaneously implementing actions aimed at hiding the criminal act. The final stage is characterized by the onset of socially dangerous consequences - the occurrence of material and other damage [4, p. 3-6].

Researchers explain the existence of modern corruption in different ways. At the same time, they are all unanimous in their opinion that it is a consequence of both the general processes of determining the causality of crime in general and the presence of purely specific causes and conditions. The latter are mainly associated with the state or another service, as well as with the development of organized, economic crime, the absence of effective barriers to the development of the economic interest of the criminals in the political and the use of criminal proceeds to bribe [7, p. 43-45].

The variety of reasons and conditions for committing corruption crimes necessitates an integrated approach to solving this acute social problem. The first step in the successful struggle against it has already been taken - its existence has been recognized in the state and higher political circles. Indeed, in a society in which a ban has been imposed on corruption, the fight against it is not possible. Further, it is necessary to understand that an absolute victory over corruption is impossible. Moreover, in the normal state of power and society, cases of corruption are kind of signals that denounce problems in the functioning of government bodies. The fight against corruption cannot be a one-time company; this area of the state's activity should be continuous and comprehensive. The organization of an anti-corruption legal policy should be dynamic and responsive to the variability of crime.

\section{CONCLUSION}

In conclusion, agreeing with the opinion of the international organization Transparency International, it should be noted that the main cause of corruption in our state is that the existing democratic institutions of civil society and the rule of law are often replaced by imitation of them. In this regard, to minimize corruption crimes in Russia, it is necessary to implement the following measures:

- make changes to the national legislation, supplementing it with norms aimed at protecting persons who have reported facts of corruption offenses;

- ratify the Council of Europe Convention on Civil Liability for Corruption and implement its provisions in national legislation;

Continuously implement the anti-corruption obligations undertaken under international anti-corruption law;

- minimize the influence of the authorities on civil society institutions and the media, and at the same time actively respond to the message of journalists and activists about the unlawful activities of officials and other information about violations of anti-corruption legislation; - to encourage scientific development of the anti-corruption problem, the organization of scientific and representative events of various levels devoted to this topic with the aim of disseminating and enriching knowledge in the field of research and finding scientifically based ways to solve existing problems;

- ensure the availability of information and data at all levels [6].

Of course, the aforementioned implies the need for reorganization measures in the structure of state power, the introduction of appropriate amendments to national legislation and, as a consequence, significant material costs, but the damage caused by corruption crimes to society and the state is so great that any reasonable investment in anti-corruption policies will exceed material costs and ensure the triumph of law and order in the country.

\section{REFERENCES}

[1] G. V. Dashkov, "The criminological essence of corruption and corruption crime", Modern problems of criminal policy: Sat. Materials Intern. scientific and practical. conf., Krasnodar, 2014, pp. 103-110 (109).

[2] P. I. Ivanov. and R. Sh. Shegabudinov, "Economic and corruption crime and its latency as an object of criminological study", Bulletin of economic security, 2017, no. 3, pp. 111-120 (112).

[3] Yu. M. Antonyan, D. A. Brazhnikov, M. V. Goncharova, and etc., "A comprehensive analysis of the state of crime in the Russian Federation and calculated options for its development: an analytical review", M.: FGKU VNII MIA of Russia, 2018, 86 p. (s. 42).

[4] A. M. Kustov, "Some features of the mechanism for committing corruption crimes", Transactions of the Academy of the Ministry of Internal Affairs of Russia, 2012, no. 2, pp. 3-6.

[5] "On anti-corruption: Feder", Law of 25 December, 2008, no. 273-FZ, Russian Newspaper, no. 266, 30 December, 2008. 
[6] Russia in the corruption perception index - 2018 [Electronic resource]. Available at: https://transparency.org.ru/research/v-rossii/rossiya-vindekse-vospriyatiya-korruptsii-2018-28-ballov-iz-100-i-138mesto.html (Accessed: 29 June 2019).

[7] O. A. Salkutsan, "Determinants of corruption crime", Modern Society and Law, 2014, no. 2, pp. 43-45.

\section{[8]}

Electronic

resource.

Available https://ria.ru/20190409/1552499622.html (Accessed: 29.06.2016)

[9] Electronic resource. Available at: http //www.cdep.ru/index.php?id=79\&item=3490 (Accessed: 29.06.2016).

[10] Electronic resource. Available at:

http://www.cdep.ru/index.php?id=79\&item=4759 (Accessed: 29.06.2016). 